\title{
An effect of credit to entrepreneurship and micro small and medium enterprises performance in Jambi Province
}

\author{
Etik Umiyati*; Zulfanetti
}

Department of Economics, Faculty of Economics and Business, Universitas Jambi, Indonesia

To whom correspondence should be addressed. Email: Umiyati.etik@yahoo.com

\begin{tabular}{|l|l|l|l|l|}
\hline DOI: & Received: & Revised: & Accepted: & Published: \\
10.22437/ppd.v9i5.11225 & 01.12 .2020 & 20.12 .2021 & 28.12 .2021 & 31.12 .2021 \\
\hline
\end{tabular}

\begin{abstract}
This research aimed at analyzing 1) an effect of micro small and medium enterprises on entrepreneurship activity, 2) an effect of micro small and medium enterprises on its performance, 3) an effect of entrepreneurship on micro small and medium enterprises performance, 4) an indirect effect of micro small and medium enterprises credit to micro small and medium enterprises through Jambi Province. This research is conducted in Jambi Province by sampling approximately 276 business owners selected according to regional representatives with purposive random sampling. PLS-SEM analysis is used in this research in which the results are 1) micro small and medium enterprises credit has a positive and significant influence on entrepreneurship, 2) micro small and medium enterprises credit has a positive and significant to micro small and medium enterprises performance, 3) micro small and medium enterprises credit has significantly positive influence to micro small and medium enterprises performance, 4) the effect of entrepreneurship to micro small and medium enterprises performance are significantly positive.
\end{abstract}

Keywords: Credit, Entrepreneurship, Micro small and medium enterprises

JEL Classification: L25, L26, M21

\section{INTRODUCTION}

Micro Small and Medium Enterprises (MSME) is considered one of the country's economic growth stimuli. This condition can be found in micro, small, and medium enterprises' performance and contribution to Indonesia's Gross Domestic Product (GDP). According to Indonesia Statistics Bureau, Indonesian MSMEs in 2018 reached 58.97 million business units. Meanwhile, in 2019 there was an enhancement to 59.2 million. MSMEs contributed to the labor absorption in 2018, approximately around 58.9, which is about $96 \%$ of 170 million active labor. In 2019 labor absorption had increased 60\% from the Indonesian GDP total, around Rp. 8.400 trillion.

MSMEs often face principle problems, like capital. There are still numerous MSME that has not been reached out to by the financial sector. Neither all micro MSME find credit facilities nor countless business units access the formal credit institution. Other weaknesses are the limited quality of human resources, difficulty of raw materials, or limitation of innovation and technology. Entrepreneurship and market- 
oriented affected in innovation and profitability of small businesses (Baker \& Sinkula, 2009). Indonesian Bank (2018) showed total credit allocation to micro small and medium enterprises in Indonesia during $2017 \mathrm{Rp} 990.377,60$ billion and increased to Rp 1.086.082,3 billion in 2018 .

Bank credit is one of the capital source alternatives to MSMEs. The lack of entrepreneurship passion is the factor that causes the low accessibility of micro, small and medium enterprises to financial institutions. The creative business will encourage the emergence of new Business-Owners to create innovative products that can penetrate International Markets. Baker and Sinkula (2009) stated that entrepreneurship-oriented and the market were affected by small business innovation and profitability. Gomet et al. (2010) and Jaworski \& Kohli (1993) market-oriented affected business performance. David Mc Clelland from the USA stated an advanced country would emerge if the minimum amount of entrepreneurs were $2 \%$ of the population (Mudjiarto, 2006). The number of entrepreneurs will be discovered by measuring the entrepreneurship activity level (Naude, 2008).

Armstrong (2014) stated MSMEs are necessary for analyzing performance to give out feedback in completing obstacles. Arif et al. (2013) stated a positive relationship between entrepreneurship oriented in increasing small business manufacturing performance. According to the Central Bank of Indonesia (2014), the number of entrepreneurs in Indonesia was $1.65 \%$. This score was lower than Malaysia, Thailand, and Singapore that successfully reaching out 7.2\%. Furthermore, The Global Entrepreneurship and Development Index (2014) stated the soundness of the Indonesian entrepreneurship ecosystem was in 68 from 121 countries. Then, 'The EYG Entrepreneurship Barometer 2013', Indonesia in between G20 countries was in Quarter 4, which possesses the lowest position in entrepreneurship. For the most part, Indonesian entrepreneurship dominated by MSMEs was $99.9 \%$, in the meantime $0,1 \%$ was leftover. The entrepreneur categories were Conglomerates and large-scale businesses (Mulyati, 2016).

Mulyono (2006), MSMEs credit has a positive effect on business volume in which accepted credit is used for purchasing raw materials and production tools, which will increase business volume. MSMEs were likely to be contributed to growth, job opportunity, and social progress (Harash et al., 2014). The development of MSMEs credit in Jambi can be measured from the magnitude of nominal value increasing. Some factors to MSMEs performance from some business units and job opportunity.

In 2017, the number of MSMEs credit given off Rp 12.331.149 million with the number of business units was 100.898 units. Labor absorption in MSMEs sector 175.765 people with a turnover was approaching Rp 3.975.600.754.566 (Central Bank of Indonesia and Micro small and medium enterprises agency in Jambi, 2017). Jambi city possesses the largest amount of MSMEs credit. However, the growing amount of business unit development and labor is slowing down and has a large turnover. On the contrary, MSMEs distribution in Tanjung Jabung Timur Regency is relatively smaller than other regions; however, business units and labor growth are relatively higher than turnover.

Although small businesses had a role in labor absorption, there has been some limitation of bank accessibility and competitive market. In so doing, they could survive only but hard to develop (Haryadi, 2016). As the researchers mentioned above, this research aimed to analyze the effect of credit on entrepreneurship and MSMEs performance in Jambi Province. 


\section{METHODS}

This research utilizes a primary source of data obtained directly from respondents and secondary data like articles and related publications/reports/journals. The data collecting method used in this research is field research by conducting surveys, interviews, and questionnaires. The research populations are MSME Owners. According to Micro small and medium enterprises agency, there had been 184.124 business units of MSMEs in 2018, located in 2 (two) cities and 9 (nine) regencies.

From a sample of $276 \mathrm{MSME}$ actors in Jambi Province, 163 respondents use MSME loans. Furthermore, from the number of respondents, as many as $163 \mathrm{MSME}$ actors were used as samples to analyze the influence of MSME credit on entrepreneurship and the performance of micro, small and medium enterprises in Jambi Province.

Partial Least Square (PLS) with Warp-PLS Version 5 is used in analyzing this credit effect on entrepreneurship and MSMEs performance. There are 2 exogenous and endogenous variables. The exogenous variable is $\operatorname{MSMEs}(\mathrm{X})$. meanwhile, latent endogenous variables $(\mathrm{Y})$ are entrepreneurship and MSMEs performance.

Subsequent, in Figure.1 is illustrated conceptual research framework associated with observed variables. It shows and describes relationships among observed variables and positive and negative variables, having the form symmetrical, causality, or interactive.

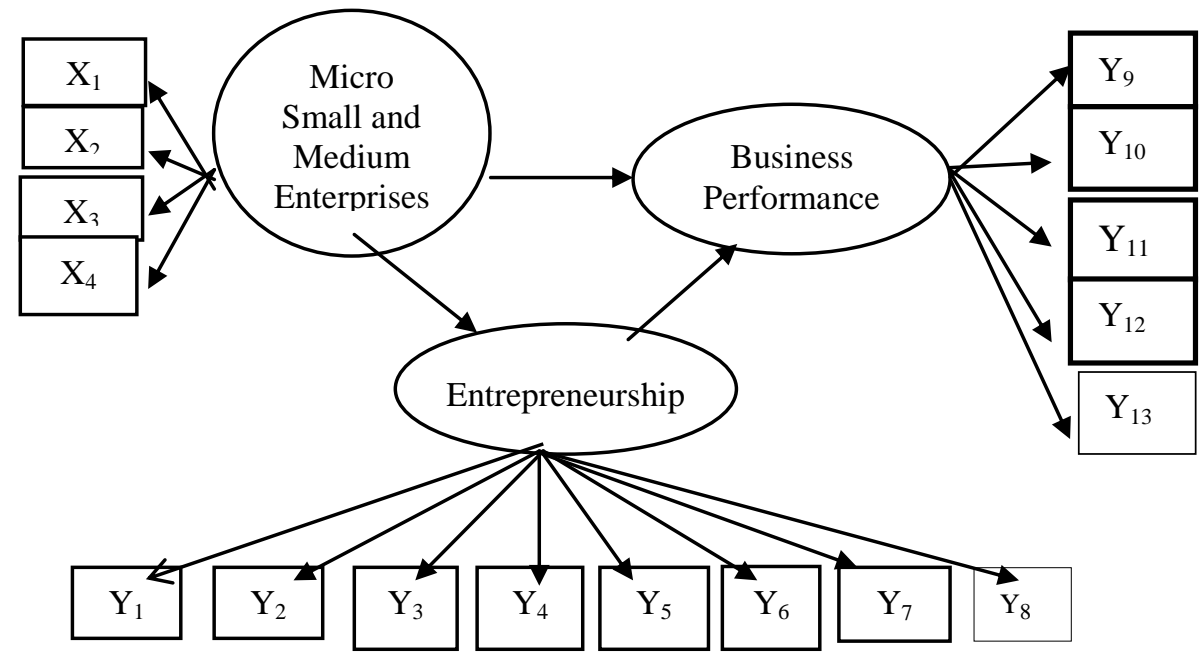

Figure 1. Research model

Notification:

$\mathrm{X}_{1}=$ education and training

$\mathrm{X}_{2}=$ accessibility market information

$\mathrm{X}_{3}=$ partnership pattern

$\mathrm{X}_{4}=$ capital loan

$\mathrm{Y}_{1}=$ strategically plan

$\mathrm{Y}_{2}=$ resources combination

$\mathrm{Y}_{3}=$ self-discipline

$\mathrm{Y}_{4}=$ creativity

$\mathrm{Y}_{5}=$ innovative

$\mathrm{Y}_{6}=$ motivation

$\mathrm{Y}_{7}=$ brave and risk 


$\begin{array}{lll}\mathrm{Y}_{8} & = & \text { self-confidence } \\ \mathrm{Y}_{9} & = & \text { average selling } \\ \mathrm{Y}_{10} & = & \text { average production } \\ \mathrm{Y}_{11}= & \text { amount of asset } \\ \mathrm{Y}_{12}= & \text { profit } \\ \mathrm{Y}_{13}= & \text { amount of labor }\end{array}$

Hair et al. (2013) stated there were 2 (two) criteria to assess whether outer model qualify convergence validity to reflective construction, viz. (1) loading factor score must higher $0.70(2)$ significance level $(<0.05)$

\section{RESULTS AND DISCUSSION}

\section{Convergent validity}

Convergent validity is a measurement model with indicator reflective assessed by correlation between component score with construct score by PLS. The validity test can be analyzed in cross-loading, an indicator considered valid; if convergent validity is higher than 0,70 or approximately $0.50-0.60$, it will be accepted (Ghozali, 2016).

Table 1. Outer loading

\begin{tabular}{crrrr}
\hline Variable & Credit & Entrepreneurship & Performance & p-Value \\
\hline X1 & 0.697 & 0.032 & 0.071 & $<0,01$ \\
X2 & 0.783 & 0.077 & 0.012 & $<0,01$ \\
X3 & 0.695 & 0.028 & 0.043 & $<0,01$ \\
X4 & 0.753 & 0.072 & -0.042 & $<0,01$ \\
Y1 & 0.359 & 0.631 & 0.185 & $<0,01$ \\
Y2 & 0.180 & 0.803 & 0.046 & $<0,01$ \\
Y3 & 0.069 & 0.822 & 0.057 & $<0,01$ \\
Y4 & 0.069 & 0.784 & -0.000 & $<0,01$ \\
Y5 & 0.074 & 0.774 & 0.049 & $<0,01$ \\
Y6 & 0.006 & 0.716 & 0.088 & $<0,01$ \\
Y7 & 0.119 & 0.844 & 0.085 & $<0,01$ \\
Y8 & 0.149 & 0.853 & 0.180 & $<0,01$ \\
Y9 & 0.421 & 0.106 & 0.656 & $<0,01$ \\
Y10 & 0.146 & 0.042 & 0.868 & $<0,01$ \\
Y11 & 0.158 & 0.000 & 0.682 & $<0,01$ \\
Y12 & 0.046 & 0.109 & 0.907 & $<0,01$ \\
Y13 & 0.105 & 0.073 & 0.597 & 0,05 \\
\hline
\end{tabular}

SEM-PLS test, micro small and medium enterprises credit has loading factor value between $0.695-0.783$ higher than critical limit 0.6 , in so doing qualify convergent validity. All indicators from 4th dimensions variables micro small and medium enterprises reflected robust correlation.

Education and training indicators $\left(\mathrm{X}_{2}\right)$ possess the highest value in MSMEs credit, viz. 0,783. If there is an enhancement of MSMEs credit, education, and training will increase. Education and training MSMEs are very useful for business continuity, particularly production marketing, business administration training, and financial management.

Indicator accessibility of market information $\left(X_{3}\right)$ has the smallest value than others, viz. 0.69. It is acknowledged that the access point for market information for MSMEs is still limited, particularly information path related to product planning and description of market needs. 
Entrepreneurship has a loading factor value of $0.622-0.853$ which means that all indicators in the entrepreneurship variable qualify convergent validity because it has a value higher than 0.60 . The combination resources indicator $\left(\mathrm{Y}_{2}\right)$ has a value of 0.803 . Business-Owners in combining resources are related to using capital, raw materials, and labor in a more appropriate, cheap, and timely manner. The self-discipline indicator $\left(\mathrm{Y}_{3}\right)$ has an outer loading value of 0.822 . It means that with entrepreneurship, selfdiscipline in MSMEs actors will also increase. The value of self-discipline is related to the ability of a business owner to complete every job completely, on time, and with full attention in providing services to customers. Business people who have self-discipline will use the capital loan they get according to their business needs to avoid credit arrears. The loading factor value for the motivation or motivation indicator $\left(\mathrm{Y}_{6}\right)$ is 0.716 , with the smallest value compared to other indicators. Motivation is related to the ability of business actors to find solutions to problems faced for business development and to accept new ideas in business activities more precisely and better.

Brave and risk indicator $\left(\mathrm{Y}_{7}\right)$ possess loading factor value 0.844 , which means if there is an enhancement of entrepreneurship, business owners will also increase the courage over risk. The highest loading factor score is one of the strengths for MSMEs Owners in Jambi Province. The business owners must make-decision, receive brainchild, leverage business opportunities in facing competition. Furthermore, the selfconfidence indicator (Y8) loading factor is 0,853 , the most dominant and robust factor in entrepreneurship. Business owners must be an optimist in solving problems and has a market scale.

Business performance possess loading factor 0,597 - 0,907. The turnover indicator gives out the highest loading value between business performance indicators, viz. 0.907 means the enhancement of business performance will influence selling turnover. Labor indicator possesses loading value 0.597 less than critical limit 0,60. Even though these indicators are still being maintained, Ghozali stated loading 0.5 is still tolerated. Aside from that, after respecification, if the labor indicator is eliminated, the researchers could not eliminate the labor variable.

\section{Discriminant validity}

To evaluation of discriminant validity will be analyzed from square roots average variance extracted (AVE) viz. diagonal column and given off brackets (Sholihin \& Ratmono, 2013). They should be higher than the correlation between latent variables in the same column.

Table 2. Output correlation in between latent variable and AVE

\begin{tabular}{lccc}
\hline \multicolumn{1}{c}{ Latent Variable } & Credit & Entrepreneurship & Performance \\
\hline Credit & $(0,706)$ & 0,331 & 0,194 \\
& $(1.000)$ & $(<0.01)$ & 0.018 \\
Entrepreneurship & 0,331 & $(0,758)$ & 0,243 \\
& $(<0.01)$ & $(1.000)$ & $(0.003)$ \\
Performance & 0,194 & 0,243 & $(0,617)$ \\
& $(0.018)$ & $(0.003)$ & $(1.000)$ \\
\hline
\end{tabular}

Discriminant validity score construct variable credit has been qualified, due to AVE roots 0.706, it is highest than 0.331 and 0.194 . Entrepreneurship construct variable is obtained roots AVE $=0.758$, higher than 0.331 and 0.243 . Performance construct possesses roots AVE 0.617. Diagonal latent line in latent variable correlations shows discriminant validity for all variables is excellent, with a score $>0.60$. It means 
respondents have no difficulty in answering the questionnaire. It can be concluded all latent variables qualify criteria and have no discriminant validity.

\section{Reliability test}

There are two measures of instrument reliability in a study, namely composite reliability and Cronbach's alpha, where both must have a value above 0.60 . The greater the reliability value (closer to number 1), the higher the confidence level of the instrument. The following is the value of composite reliability and Cronbach's alpha.

Table 3. Reliability test

\begin{tabular}{lccc}
\hline Construct & Composite Reliability & Cronbach's Alpha & Explanation \\
\hline Credit & 0.682 & 0.707 & Reliable \\
Entrepreneurship & 0.914 & 0.892 & Reliable \\
Performance & 0.703 & 0.606 & Reliable \\
\hline
\end{tabular}

The results showed that the value of composite reliability and Cronbach's alpha on the variables of MSME credit, entrepreneurship, and performance had met the requirements, so it can be concluded that the measurements in this study were reliable.

\section{Collinearity test}

Vertical collinearity is the collinearity between predictor variables in the same block. Meanwhile, lateral collinearity is the collinearity between the latent variables of the predictors and the criteria (Ratmono \& Sholihin, 2013). The Criterion for a full collinearity test is that the value must be low than 3.3 (Kock, 2013). The results of the multicollinearity test in this study can be seen in Table 4

Table 4. Full collinearity test VIFs

\begin{tabular}{lcc}
\hline \multicolumn{1}{c}{ Construct Variables } & Full Collinearity VIFs & Explanation \\
\hline Credit & 1.140 & No Multicollinearity \\
Entrepreneurship & 1.166 & No Multicollinearity \\
MSME Performance & 1.079 & No Multicollinearity \\
\hline
\end{tabular}

Based on the research results in Table 4, it shows that the full collinearity VIF value is less than 3.3 , so that the model is free from collinearity problems.

\section{Research model test}

One of the research model test objectives is to compare the best model between different models. In Ratmono and Sholihin (2013), the WarpPLS Version 5 program can produce several fit indicators, including average R-squared (ARS), average path coefficient (APC), and average variance inflation factor (AVIF). Evaluation of model fit can be seen from the p-value for APC and ARS, which must be less than 0.05 or it means significant. The AVIF value as an indicator of multicollinearity must be less than 5. Based on the results of the research, the results of the fit model are as follows:

Table 5. The output of the research model test

\begin{tabular}{lrl}
\hline Information & Value & \multicolumn{1}{c}{ Criteria } \\
\hline Average path coefficient (APC) & 0.249 & $\mathrm{P}<0.01$ \\
Average R-squared (ARS) & 0.316 & $\mathrm{P}=0.037$ \\
Average adjusted R-squared (AARS) & 0.307 & $\mathrm{P}=0.046$ \\
Average block VIF (AVIF) & 1.127 & Acceptable if $<=5$, ideally $<=3.3$ \\
Average full collinearity VIF (AFVIF) & 1.129 & Acceptable if $<=5$, ideally $<=3.3$ \\
Tenenhaus GoF (GoF) & 0.326 & Small $>=0.1$, medium $>=0.25$, large $>=0.36$ \\
Symson's paradox ratio (SPR) & 1 & Acceptable if $>=0.7$, ideally $=1$ \\
R - squared contribution ratio (RSCR) & 1 & Acceptable if $>=0.9$, ideally $=1$ \\
Statistical suppression ratio (SSR) & 1 & Acceptable if $>=0.7$ \\
Nonlinear bivariate causality direction ratio (NLBCDR) & 0.833 & Acceptable if $>=0.7$ \\
\hline & &
\end{tabular}


Based on the output results, the criteria for the goodness of fit model have been met, namely the Average path coefficient (APC) value of 0.249 with a significance of $p$ $<0.001$ and the Average R-squared (ARS) of 0.316, significant at $\mathrm{p}<0.05$. The AVIF value of 1.127 also meets the criteria. Furthermore, the goodness of fit $(\mathrm{GoF})$ value of 0.326 is in the medium, greater than 0.25 , which means that the results of this test show that the overall model is good and able to reflect research phenomena.

\section{Structural model evaluation analysis (inner model)}

The structural model in WarpPLS version 5 is evaluated using the R-square for the dependent construct, path coefficient estimation, and prediction relevance (Q2) (Ghozali, 2011).

\section{Coefficient of determination $\left(\boldsymbol{R}^{2}\right)$}

According to Chin in Ghozali (2011), $\mathrm{R}^{2}$ results of 0.67 for endogenous latent variables in the structural model indicate a good model, $\mathrm{R}^{2}$ value of 0.33 is called moderate, and $\mathrm{R}^{2}$ is 0.19 for a weak model. Based on the research results, the coefficient of determination is obtained as follows:

Table 6. Coefficient of determination value $\left(\mathrm{R}^{2}\right)$

\begin{tabular}{lcc}
\hline Variable & $R$-square & Explanation \\
\hline Entrepreneurship & 0.569 & Moderat \\
MSME Performance & 0.478 & Moderat \\
\hline
\end{tabular}

In Table 6, from the data processing results on 163 MSME players who received MSME credit in Jambi Province, the $\mathrm{R}^{2}$ value for the variable credit to entrepreneurship was 0.569 , which means that MSME credit could explain entrepreneurial variance by $56.9 \%$. Furthermore, the MSME credit and entrepreneurship variables could explain the performance variance of micro, small and medium enterprises by $47.8 \%\left(R^{2}=0.478\right)$.

\section{$Q$ - squared value}

Q-Squared assesses the predictive validity or relevance of a set of predictor latent variables on the criterion variable. A model is good if the predictive validity (Qsquared) has a value greater than zero (Ratmono and Sholihin, 2013). Based on the estimation results of the model in this study, a good Q-Squared value is obtained, namely 0.214 for entrepreneurial variables and MSME performance variables of 0.122.

Table 7. $Q$-squared Value $\left(\mathrm{Q}^{2}\right)$

\begin{tabular}{lcc}
\hline Variable & $R$-square & Explanation \\
\hline Entrepreneurship & 0.214 & $\mathrm{Q} 2>0$ \\
MSME Performance & 0.122 & $\mathrm{Q} 2>0$ \\
\hline
\end{tabular}

Based on the results of the estimation model in this study, it was obtained a good Q-Squared value of 0.214 for entrepreneurial variables and MSME performance variables of 0.122 .

\section{Estimated path coefficients (path analysis)}

The results of the path coefficient estimation are used to analyze the effect of MSME credit on entrepreneurship and the performance of micro, small and medium enterprises in Jambi Province. 
Table 8. Path analysis result

\begin{tabular}{clrrrr}
\hline Hypothesis & Relation & Coefficient & $\mathrm{p}$-Value & Ideal & Result \\
\hline H1 & Credit-Entrepreneur & 0.522 & $<0.01$ & $<0.05$ & Accepted \\
H2 & Credit-Performance & 0.244 & 0.04 & $<0.05$ & Accepted \\
H3 & Entrepreneur-Performance & 0.451 & $<0.01$ & $<0.05$ & Accepted \\
H4 & Credit-Entrepreneur- & 0.235 & 0.042 & $<0.05$ & Accepted \\
& Performance & & & & \\
\hline
\end{tabular}

Table 8 shows that the path coefficient between MSME credit and entrepreneurship is positive, namely 0.522. It means that if there is an increase in MSME credit, entrepreneurship will also increase. The direct effect is significant with the probability value $(\mathrm{p}<0.01)$.

The MSME credit variable on the performance of micro, small and medium enterprises has a positive direct effect, namely 0.244 with a significance level of $\mathrm{p}=$ $0.04(\mathrm{p}<0.05)$. It means that an increase in MSME credit will improve the performance of micro, small and medium enterprises.

Furthermore, there is a positive and significant influence between entrepreneurship on the performance of micro, small and medium enterprises of 0.451 with a significance level $(\mathrm{p}<0.01)$. It means that if entrepreneurship increases, it will increase the performance of micro, small and medium enterprises.

The influence of MSME credit on the performance of micro, small and medium enterprises indirectly through entrepreneurship has a positive value of 0.235 with a significance level of $\mathrm{p}<0.05$.

\section{The effect of MSME credit on entrepreneurship}

MSME credit has a positive and significant direct effect on entrepreneurial variables in MSME actors in Jambi Province. It can be seen from the positive path coefficient of 0.522 , meaning that if there is an increase in MSME credit, it will increase entrepreneurship among MSME actors in Jambi Province. The increase in UMKM credit given to business actors means a tendency for entrepreneurship to increase. It is known that the direct effect is significant with the probability value of the path coefficient $(p<0.01)$. Based on the results of data analysis, the value of $R^{2}=0.574$ was obtained, which means that micro, small and medium enterprise (MSME) credit can explain the entrepreneurial variation of $57.4 \%$.

Entrepreneurship variables are measured using 8 (eight) indicators: 1). Strategic planning; 2). Combine resources; 3). Self-discipline; 4). Creativity; 5). Innovation; 6). Motivation; 7). Courage for the risk consequences of action; and 8). Confidence.

According to Purwanti (2012), business capital has a positive and significant effect on business development, so that it requires ease in obtaining business capital at an affordable interest rate.

According to Minniti (2008), government policies in capital or financial assistance can increase entrepreneurship. Furthermore, the same research was also conducted by Olu (2009), who analyzed the impact of microfinance on the entrepreneurial development of small businesses in Nigeria. The results showed a significant relationship between microfinance institutions' productivity and entrepreneurship development.

Research by Quaye (2011) also shows that microfinance positively affects the growth of small businesses in Kumasi, Ghana. Microfinance institutions increase SMEs' 
access to credit, savings, financial and managerial training. Furthermore, the results of this study are also strengthened by research by Obaji and Olugu (2014), which states that the success of entrepreneurship in several countries is influenced by government policies, one of which is financing in the financial sector.

\section{The influence of MSME credit on the performance of micro, small and medium enterprises}

The quantitative performance measurement can be seen from the average amount of wealth owned by MSMEs (assets), the average profit gained (Profit), the average production (Production), the average turnover, and the number of workers used in the production process.

The research results show that the direct effect of MSME credit and business performance has a positive and significant direction of 0.244 . A positive coefficient value means that if there is an increase in MSME credit, it will cause the performance of micro, small and medium enterprises also to increase. The direct effect is significant, with a p-value of $0.04(\mathrm{p}<0.05)$. It indicates that MSME loans provided by financial institutions have a very important role in increasing income. The results of this study support the theory of Kasmir (2011), which states that credit can positively increase income, because the provision of credit can increase business capital.

This research aligns with what Akoten, Sawada, \& Otsuka (2006) conducted on garment SMEs in Kenya. The research results show that SMEs borrow from various formal and informal credit sources (ROSCA). Credit has a significant effect on profitability and job opportunities.

Credit as a source of capital is closely related to small business activities to increase production, which will increase entrepreneurs' profits and income. The credit obtained allows business actors to have more cash and additional liquidity that can be used to finance the purchase of production inputs until optimal conditions are achieved.

Purchases of production inputs can be in the form of additional purchases of raw materials, purchases of supporting materials, an increase in the number of workers. Furthermore, using these raw materials in the production process will increase production capacity or output so that MSMEs' turnover or sales volume will increase. The increase in production output will also increase business revenue. Coleman (1999) states that research on the impact of credit can be seen from several aspects, including: (1) aspects of physical assets, (2) savings, debt, and loans, (3) aspects of production, sales, purchases, and working time, and (4) aspects of education and health.

\section{The influence of entrepreneurship on the performance of micro, small and medium enterprises}

MSME resource development is an individual or group preparation for a set of information, knowledge, and knowledge to achieve certain competencies to have new standards, knowledge, attitudes, skills, and responsibilities in developing their business. Business actors are generally provided with entrepreneurial training/provisioning, not automatically integrated.

The relationship of motivation, innovation, and risk with performance is explained by Noersasongko (2005) which states that entrepreneurship is considered to have a dominant influence on business success. It is also supported by Kao (2001), which states that small companies that want to develop must have an entrepreneurial spirit; besides, Gray (2002) emphasizes that small business owners can outperform 
their competitors with the entrepreneurial spirit. Georgellis et al. (2000) stated that their capacity to innovate and the courage to take risks develop successfully.

This condition is also confirmed by Munizu (2010) which states that internal factors consisting of human resources, financial aspects, technical aspects of production or operations, and market and marketing aspects have a positive and significant impact on the performance of micro and small businesses.

\section{The effect of MSME credit on the performance of micro, small and medium} enterprises through entrepreneurship

This research indirectly shows a positive influence between MSME credit and business performance through entrepreneurship variables of 0.235. MSME credit indirectly positively affects business performance through entrepreneurship with a probability value of $0.042(\mathrm{p}<0.05)$. This study shows that entrepreneurship variables mediate the effect of MSME credit on the performance of micro, small and medium enterprises. It indicates that the entrepreneurial ability of MSME actors in Jambi Province has good capacity. The biggest indicators that shape entrepreneurship are 1) Strategic planning, 2) Combining resources, 3) Self-discipline, 4) Creativity, 5) Innovation, 6) Motivation, 7) Courage due to the risk of action, 8) Self-confidence.

Credit is one of the sources of funding obtained through financial/banking institutions for MSMEs, which is needed to improve and develop their business. Hidayat and Herlambang (2009) stated that the assistance of State-Owned Enterprises (BUMN) and bank credit does not necessarily improve performance but instead reduces it. This statement is also supported by Imam Santoso (2015) based on his research on MSME Agroindustry in Mojokerto Regency, East Java. His research results show that credit does not directly affect the performance of MSMEs.

Business development, either in the form of training or assisting in business capital loans, is expected to increase the entrepreneurial behavior of MSME players in Jambi Province. Managing businesses that are at least based on entrepreneurial orientation is expected to encourage business actors to improve their business performance. In other words, the better the implementation of entrepreneurial orientation and market orientation in business governance will increase the resulting business performance.

\section{Testing the entrepreneurial behavior variable as a mediating variable using the variance accounted for (VAF) method.}

Variance Accounted For (VAF) measures how much the mediating variable can absorb the previously significant direct effect of the model without mediation (Hair et al., 2013). Several steps must be considered in calculating the mediating variable: 1) The direct effect must be significant when the mediating variable has not been included. 2) The indirect effect must be significant if the model includes the mediating variable. 3) Calculating VAF using the formula for the indirect effect divided by the total effect. If the VAF value is between $20 \%-80 \%$, it is categorized as a partial mediator. But if the VAF value is less than $20 \%$, it can be concluded that there is no mediating effect (Hair et al., 2013)

The effect of MSME credit on the performance of micro, small and medium enterprises in the absence of entrepreneurial behavior variables obtained a coefficient value of 0.183 with a significance level $(p<0.01)$. Based on the results in the image below, it is obtained that the R-squared value is 0.25 , which means that the MSME 
credit variable can explain the performance of micro, small and medium enterprises by $25 \%$.

The indirect effect is obtained by multiplying the value of the MSME credit coefficient on entrepreneurship (0.522) and the entrepreneurial coefficient value on business performance (0.451). The results of the indirect effect are as follows: $(0.522)$ $*(0.451)=0.2354$. Furthermore, the total effect is calculated by adding the direct and indirect effects, namely $0.183+0.235=0.418$. VAF $=$ indirect effect divided by the total effect. For more details, the results of the VAF calculation can be seen in Table 9 .

Table 9. Calculation of variance accounted for (VAF)

\begin{tabular}{lc}
\hline Description & Result \\
\hline Indirect Effect $=(0.522) *(0.451)$ & 0.235 \\
Direct Effect of MSME Credit on Business Performance & 0.183 \\
Total Effect $=0.235+0.183$ & 0.418 \\
VAF $=$ Indirect Effect $/$ Total Effect & 0.563 \\
\hline
\end{tabular}

Based on the calculation results, the VAF value is 0.563 or $56.3 \%$ for the entrepreneurial variable as a mediator between MSME credit and performance. This VAF value is above $20 \%$, so it can be concluded that the entrepreneurial variable is a partial mediator. The form of partial mediation shows that entrepreneurship is not the only mediator of the MSME credit relationship to business performance. It also means that either directly or indirectly (through entrepreneurship), MSME credit still affects the performance of micro, small and medium enterprises. When viewed from the coefficient value between the direct and indirect effects, the coefficient value for the indirect effect is greater than the direct effect.

The results of the interviews revealed that MSME actors who have received entrepreneurship training generally have higher motivation and confidence in carrying out their business activities.

\section{Policy implications of research results}

MSME assistance is carried out in regular discussions, where usually the topics discussed are about the problems faced by MSMEs. The mentoring program carried out by PLUT-KUKM Jambi Province only covers two areas, namely Jambi City and Muaro Jambi Regency. For MSME, Jambi City already has a group of UMKM associations known as the Food and Beverage Association (ASMAMI) and the Muaro Jambi UMKM Association (ASUMKMUJA) for the Muaro Jambi Regency area.

The data-target program for 1000 MSME in Jambi is one of the PLUT-KUKM efforts to record 1,000 KUKMs. One of the objectives of this program is to help improve the performance of MSMEs, including production, marketing, access to finance, human resource development through entrepreneurial, technical, and managerial capacities, and institutional performance so that MSMEs have competitiveness. There are still many MSMEs in Jambi Province that do not have permits and halal certification. The MSME development program is through the Sharia Cooperative. The shift in people's mindset from conventional to Islamic banks has made many cooperatives implement the Islamic concept.

Given the magnitude of the influence of MSME credit on entrepreneurship and business performance, it is necessary to implement financial inclusion to open the widest possible access to financing sources for MSMEs. There are still many micro, small and medium business loans that do not achieve the target objectives that have 
been set. High-interest rates, guarantee systems, complicated procedures, limited sources of non-banking financing are important issues that require attention and handling from the government. The government must have a capital financing policy that supports the micro, small and medium enterprises sector to develop and become one of the supporting sectors for Indonesia's economic development.

\section{CONCLUSIONS AND RECOMMENDATIONS}

\section{Conclusions}

The models built in this study are the development and modification of various previous empirical studies. Several previous empirical studies generally use Becker's (1965) household economic theory model to analyze the behavior of farmer households. However, in this study, it turns out that household economics can be applied to small, MSME households in Jambi Province by emphasizing household characteristics, individual characteristics, and MSME business characteristics.

This study indicates that business actors' factors in taking MSME loans are sided jobs, working hours, working partners, gender, education level, length of business, household expenses, and account ownership.

This study also analyzes the effect of MSME credit on entrepreneurship and business performance. The estimation results show that: 1) MSME credit has a positive and significant effect on entrepreneurship. 2) MSME credit has a positive and significant effect on business performance. 3) Entrepreneurship has a positive and significant effect on business performance. 4) By using the Variance Account For (VAF) method, it can be concluded that the entrepreneurial variable is a partial mediator between MSME credit and business performance. The model estimation approach uses SEM-PLS.

\section{Recommendations}

The government's support and participation in fulfilling funds as business capital through bank credit for MSME entrepreneurs are needed. It is necessary to carry out entrepreneurial insight and skills training, forming an attitude always to think ahead, fostering and developing MSMEs. It aims to develop entrepreneurs without limits on time, region, age, class, and educational background.

Access to MSME financing, the credit guarantee scheme through the Credit Guarantee Institution that has been implemented by the government now needs to be expanded again so that it can reach all regions/regions that need MSME credit services.

It is necessary to have commitment, capability, and quality of guidance in government agencies, to foster entrepreneurial behavior among micro, small and medium enterprises. It also aims to promote and cultivate entrepreneurship through competency-based training and cooperation.

\section{REFERENCES}

Akoten, J.E., Sawada,Y., \& Otsuka, K. (2013). The Determinant of Credit Acces and Its Impact on Micro and Small Enterprises: The Case of Garment Producers in Kenya. Economic Development and Cultural Change, 54(4), 927-944

Armstrong, M. (2014). Armstrong's Handbook of Human Resource Management Practice Thirteenth. UK: Ashford Colour Press.

Baker, W.E. \& Sinkula, J.M. (2009). The Complementary Effects of Market Orientation 
and Entrepreneurial Orientation on Profitability in Small Businesses. Journal of Small Business Management, 47(4), 443-464

Bank Indonesia. (2014). Kredit UMKM. Retrieved from http://www.bi.go.id/id/umkm/kredit/Contents/Default.aspx.

Gomez, J., Llonch, J., \& Rialp, J. (2010). Strategic Orientation, Innovation and Performance of New SMEs. Cuadernos de Gestion. 10(ESPECIAL):85-110

Georgellis, Y., Joyce, P. \& Woods, A.. (2000). Entrepreneurial Action, Innovation and Business Performance: The Small Independent Business. Journal of Small Business and Enterprise Development, 7(1), 7-17.

Gray C., Simanjuntak, P., Sabur, L.K., Maspaitella, P.F.L. \& Varley, R.C.G. (2002). Pengantar Evaluasi Proyek. Jakarta: PT Gramedia Pustaka Utama.

Hair, J., Hult, T., Ringle, C. \& Sartstedt, M. (2013). A Primer on Partial Least Squares Structural Equation Modeling (PLS-SEM). Los Angeles: Sage.

Haryadi. (2016). Profil Dan Permasalahan UMKM Di Provinsi Jambi. Retrieved from https://www.slideshare.net/hbkooo/profil.umkmdiprovinsijambi.

Harash, E., Al-Tamimi, S., Alsaadi, J. (2014). The Influence of Finance of Performance of Small and Medium Enterprises (SMEs). International Journal of Engineering and Innovative Technology (IJEIT), 4(3), 161-167

Harash, E., Al- Tamimi, K \& Al-Timimi, S. (2014). The Relationship between Government Policy and Financial Performance: A Study on the SMEs in Iraq. Journal China-USA Business Review, 13(4), 290-295

Kao, J. (2001). Entrepreneurship, Creativity, and Organization. New Jersey: PrenticeHall.

Minniti, M.. (2008). The Role of Government Policy on Entrepreneurial Activity: Productive, Unproductive or Destructive? Entrepreneurship Theory and Practice, 32(5):779-790

Mudjiarto \& Wahid, A. (2006). Membangun Kepribadian Dan Kewirausahaan. Yogyakarta: Graha Ilmu

Mulyati, E. (2016). Kredit Perbankan Aspek Hukum dan Pengembangan Usaha Mikro Kecil Dalam Pembangunan Perekonomian Indonesia. Jakarta: PT. Refika Aditama.

Mulyono. (2006). Kajian Dampak Program Perkreditan Dan Perkuatan Permodalan Usaha Kecil Menengah Terhadap Perekonomian Daerah. Jurnal Pengkajian Koperasi dan UKM, 2(1).

Naude, W. (2008). Entrepreneurship in Economic Development. No RP2008-20, WIDER Working Paper Series, World Institute for Development Economic Research (UNU-WIDER)

Obaji, N.O. \& Mercy, U.O. (2014). The Role of Government Policy in Entrepreneurship Development Science. Journal of Business and Management, 2(4), 109-115

Ojo, O. (2009). The Impact of Microfinance on Entrepreneurial Development: The Case of Nigeria. The International Conference on Economics and Administration, Faculty of Administration and Business, University of Bucharest, Romania ICEAFAA Bucharest, 14-15th Nov 2009

Purwanti E. (2012). Pengaruh karakteristik wirausaha, modal usaha,strategi pemasaran terhadapperkembangan UMKM di Desa Dayaan dan Kalilondo Salatiga. Among Makarti, 5(9), 13-28. 
Quaye, D.N. (2011). The Effect of Micro Finance Institutions on the Growth of Small and Medium Scale Enterprises (SMEs); A Case Study of Selected SMEs in the Kumasi Metropolis. [Thesis] Master of Business. Kwame Nkrumah University of Science and Technology.

Sholihin, M. \& Ratmono, D. (2013). Analisis SEM-PLS dengan WarpPLS 3.0 untuk hubungan Nonlinier dalam Peneltian Sosial Dan Bisnis. Yogyakarta: CV.Andi Offset. article distributed under the terms and conditions of the Creative Commons 